\title{
STRONG COLUMN WEAK BEAM CONCEPT BY ANALYSING RCC MRF FRAME BY NON-LINEAR STATIC PROCEDURE
}

\author{
SANTOSH KUMAR ${ }^{1} \&$ NIRBHAY THAKUR ${ }^{2}$ \\ ${ }^{I}$ Post Graduate Student, Department of civil engineering, Chandigarh University, Mohali, Punjab, 140413, India \\ ${ }^{2}$ Assistant Professor, Department of civil engineering, Chandigarh University, Mohali, Punjab, 140413, India
}

\begin{abstract}
From the former earthquakes, plastic hinges of columns are more protuberant than plastic hinges of the beam which stretches intensification to global structural weakening and leads to loss of countless lives. Entirely the structural mechanisms pass their forces through the column and it further transfers it with foundation and finally to the soil, thus we can visualize if the column collapses whole structure can collapse, this is the concept of the strong beam and weak column. Enhancing the moment-resisting capacity of the column as compare to beams this results in the formation of plastic hinges in the beams first and avoids the global damage as the beam will show flexure as an indication of beam failure and the individuals will have tolerable time to vacate from that structure. The study is undertaken to explore the further behavior of the structure and for this investigation three RC frames of 5, 8, and 12 storey height are considered for strong column weak beam concept for Seismic Zone V, Soil type II and all the guidelines are followed as per IS 1893:2016. For inspection of the recital of plastic hinges of beam and column, non-linear static analysis is accompanied in FEM based software ETABS and the hinges are studied and confirmed conforming to accepted norms given in FEMA 356 and further base shear and performance point are discussed with displacement are checked for all frames.

KEYWORDS: E-Tabs, Pushover Analysis, Moment Capacity Ratio, Performance Point, FEMA356
\end{abstract}

Received: Jun 09, 2020; Accepted: Jun 29, 2020; Published: Jun 30, 2020; Paper Id.: IJMPERDJUN2020313

\section{INTRODUCTION}

The realization of plastic hinges in beams aids to form the utmost anticipated and appropriate energy dissipating mechanism for structure in seismic circumstances. If the plastic hinges are moulded on mutual ends of the column formerly column is not able to extend the plasticity and breakdowns which can lead to global disaster. In preceding earthquakes identical effects had happened, column fails primarily in compression than beams in flexure prime to life intimidating disorder of people in buildings. The main and common failure noticed in the historical earthquakes that were the beam column-failure, story-failure, column-collapsing onward of the beam, and short column effect. The irregular building summonses enormous base shear and they are in grander risk, but the failure of consistent frames deprived of most significant structure irregularity is the chief concern in this work. The failure modes in all the past earthquakes are practically analogous and strong beam weak column derives out to be a major problem which central column to sway and these structures also have a deficiency of ductile detailing between beam and column connections. All international codal provisions recommended strong column weak beam structural design requirements and have a different value of $\beta$ (beta) for distinctive design codes. The code provision recommended that the moment in the column should be $\beta$ times stronger than beams.

$$
\sum \mathrm{Mc} \geq \beta \times \sum \mathrm{Mb}
$$


Table 1: Values of Moment Capacity Factor for Various International Codes

\begin{tabular}{|l|c|}
\hline \multicolumn{1}{|c|}{ International Codes } & Value of $\boldsymbol{\beta}$ \\
\hline American Standard (ACI 318M-02) & 1.2 \\
\hline New Zealand Standard (NZS3101:1995) & 1.4 \\
\hline European Standard (NZS3101:1995) & 1.4 \\
\hline Indian Standard (IS13920:2016) & 1.4 \\
\hline
\end{tabular}

Pushover analysis is the static non-linear analysis and is accomplished as per the guiding principle of FEMA356, 440, and ATC40. This analysis can be operated on various packages like CSI-ETabs, SAP-2000, and Staad.Pro. The assignment of hinges can be manually or pre-available options in the software. Before assigning of hinges the structural performance is checked using linear dynamic analysis and is designed as per respective codes. Assessment of a structure under non-linear static analysis is for performance-based design which helps in designing the column and beams for the new structure and retrofits the earlier structure by checking the plastic hinge recognition criteria given by FEMA-356. Figure 1 shows the performance criteria of framing in which IO means Immediate Occupancy, LS means Life Safety CP means Collapse Prevention which comes in B to $\mathrm{C}$ which is a plastic zone in which the structure ductility yields for plastic behavior.
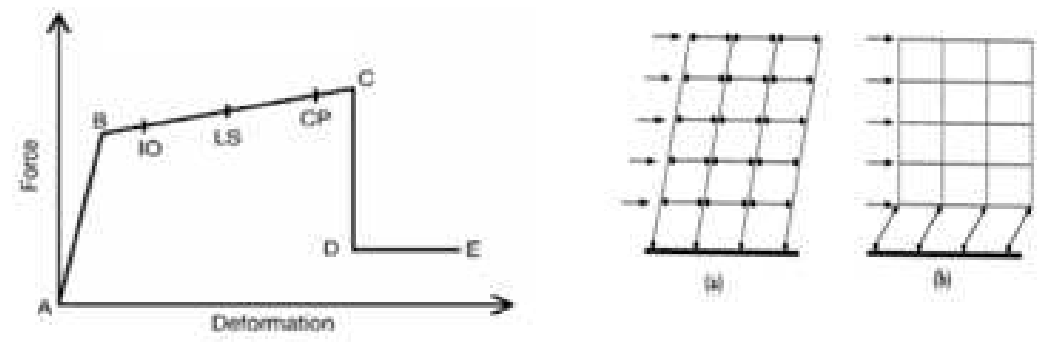

Figure 1: Shear Force vs Deformation.

A comparison of moment capacity ratio of beam and column was done by Yangbing Liu, Yuanxin Liao \& Nina Zhen 2012 by varying the capacity ratio from 0.8 to 2.2 to improve the bearing capacity at node end of column and beam has suggested that with the decrease in ductility column loses its strength and $\beta=1.2$ gives the first hinge on column base and $\beta=1.6$ gives beam sway moment. Another research by Dooley \& Bracci, 2001; Haselton et al., 2011; Ibarra \& Krawinkler, 2005 shows that for tall buildings the present over strength factor of 1.2 is not sufficient to prevent the mechanism of plastic hinges and for 4 storey and more the over strength factor of 2 shows complete beam sway mechanism suggested by (Haselton et al., 2011; Ibarra \& Krawinkler, 2005). B Shiva kumara Swamy, S K Prasad, Sunil N 2015 conclude in their research that the structure with least stiffness ratio by varying the dimension of beam and column are vulnerable to seismic excitation with the help of pushover analysis and the results are compared for different zones and soil type. A total of 15 structures of 12,18 , and 24 storey with varying capacity ratio from 1.2 to 2.0 was analyzed by Cagurangan (2015) and numerical modeling was done on openness and response of beams and column for incremental dynamic analysis was plotted on the research paper.

\section{STRUCTURE GENERAL INFORMATION}

The structural frame having G+5, G+8, and G+12 storey are considered for analysis under seismic zone 5 and medium soil condition, and all the design requirements are fulfilled as per IS456:2000 and IS1893:2016 and IS13920:2016. These frames are first designed for gravity loading and then the results of rebar percentage, column beam capacity ratio and 
seismic results are verified and if the result is passed then further pushover analysis is done for the plastic capacity of the structure by assigning hinges in beam-column and performance is checked for all frames but in some cases, beam and column dimensions are not sufficient for some combination for seismic and gravity loading so the dimensions are modified to reduce the rebar percentage for economic purpose and maintaining the column beam capacity ratio and then pushover is done to check the damage and performance of 3 frames. These frames are without dual frame structure like a shear wall, dampers, struts which helps in dissipating energy or distributing seismic energy to check the actual performance of the frame.

\section{METHODOLOGY WITH BUILDING DESCRIPTION}

The frame consists of a plan area of 25 sq. $\mathrm{m}$ having 5 bays in each direction with a span of $5 \mathrm{~m}$ and keeping the story height as $3 \mathrm{~m}$ uniform on all the three structures viz. $\mathrm{G}+5, \mathrm{G}+8$, and $\mathrm{G}+12$. The loading condition is adopted as per IS 875:1987 Part 1 for dead load and Part 2 for live load by assuming residential building. The seismic design parameters are adopted as per IS 1893:2016 and IS 13920:2016. Grade of concrete adopted for design is M25 and Fe415 as a grade of steel. Size of a beam fixed as per codal provisions as $300 * 350 \mathrm{~mm}$ and circular column of $450 \mathrm{~mm}$ diameter. Figure 2 depicts the plan view of the selected model Figure 3,Figure 4, and Figure 5 represents a 3D view of 6, 9. and 13 storey buildings.

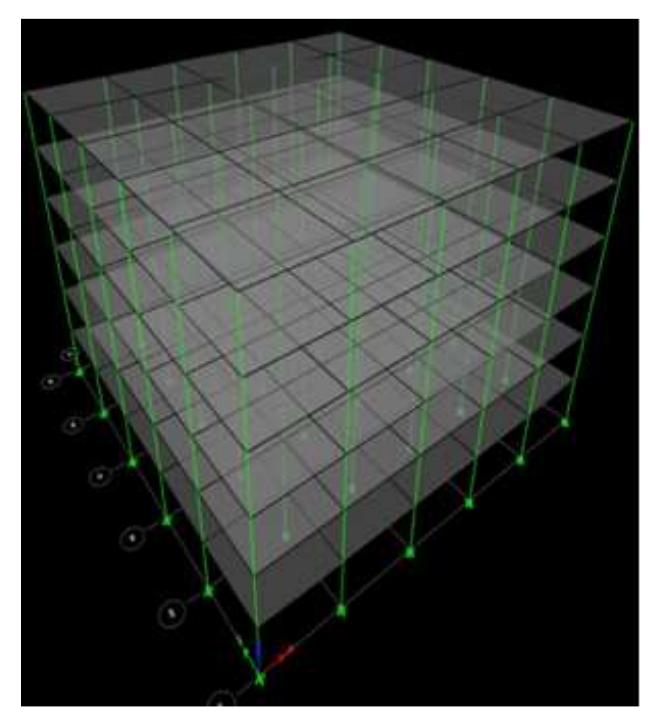

Figure 2: 3D View of $\mathbf{G + 5}$.

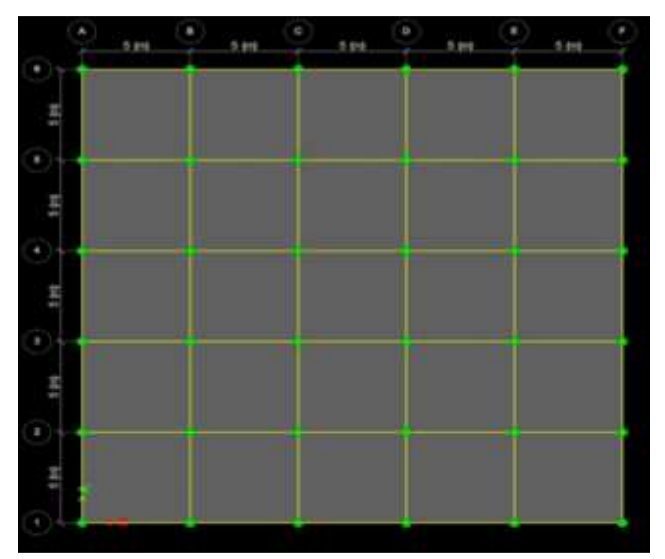

Figure 3: Plan View. 


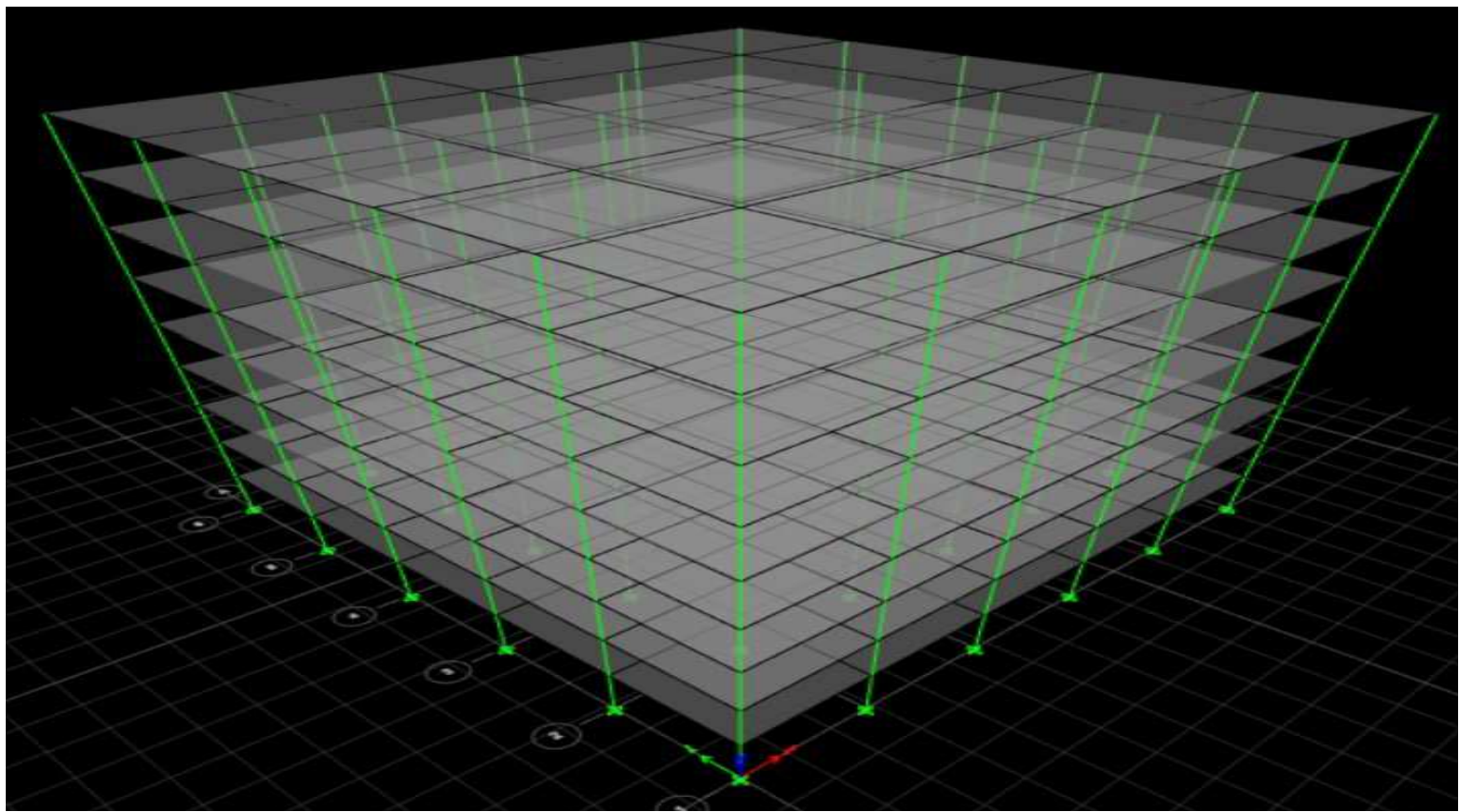

Figure 4: 3D View of G+8.

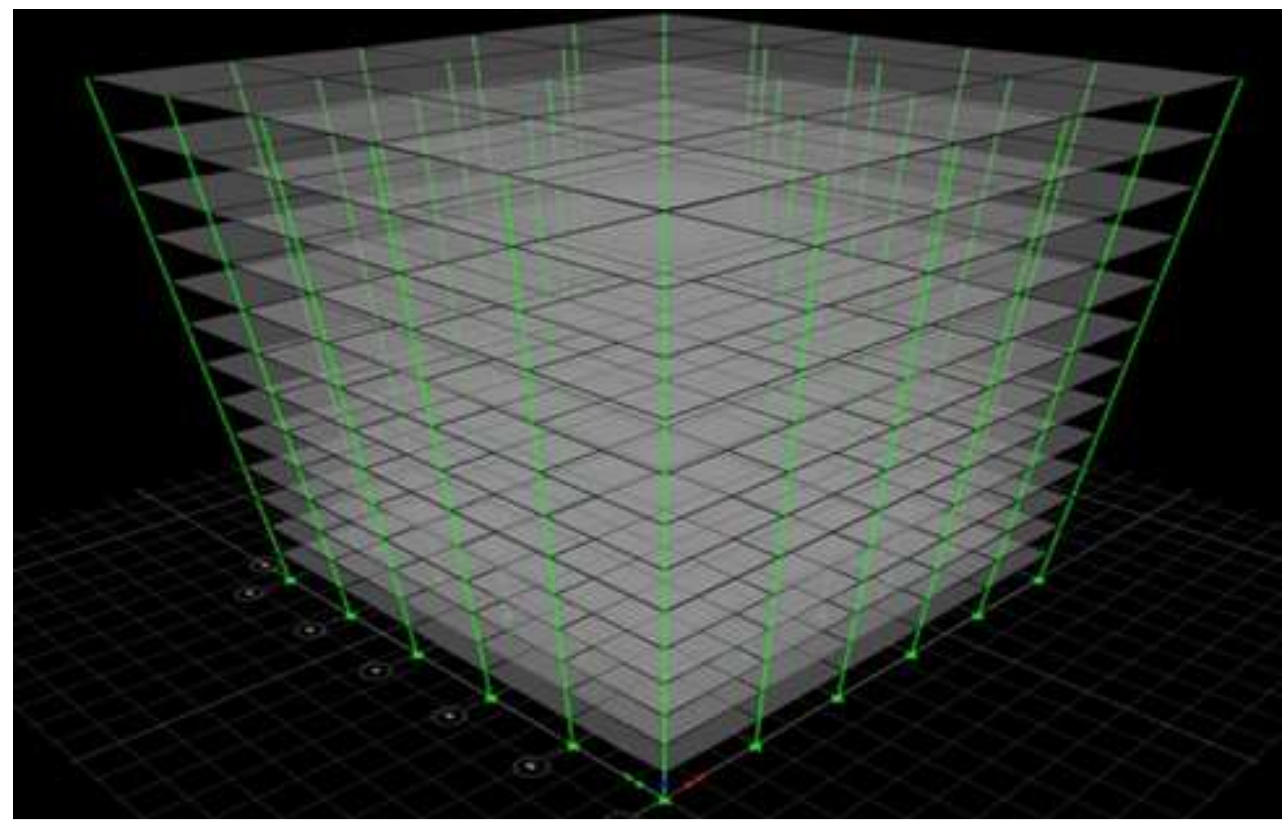

Figure 5: 3D View of G+12.

Beams are selected for hinges having parameter M3 (flexural case) and columns for P-M2-M3 at a distance of 0.1 and 0.9 from both ends. After assigning hinges the analysis was run only for dead and push cases with load combinations and results of Base shear vs. Displacement and performance points were located and frames are checked for that specific performance in which beams and column hinges was checked as per acceptance criteria in FEMA 356.

\section{RESULTS AND DISCUSSIONS}

\section{Interpretation of $\mathbf{G + 5}$ Frame}

Contrasting on the performance of 6 story building shown in Table 1 and Figure 8, the origin of hinges first observed at $49.20 \mathrm{~mm}$ displacement and maximum displacement noticed is $350.67 \mathrm{~mm}$ at $6870.68 \mathrm{kN}$ base force and after that, it is 
observed that base force starts dropping. Straining on the results of FEMA 440 curve in Figure 7,6086.8kN is observed as performance point at $220.08 \mathrm{~mm}$ displacement with ductility ratio of 2.60 , T-secant as $1.762 \mathrm{~s}$, T-effective as $1.649 \mathrm{~s}$ and spectral acceleration is observed as 0.24 corresponding to the spectral displacement of $185.9 \mathrm{~mm}$.

Table 1: Base Shear vs Monitored Displacement for G+5 Building

\begin{tabular}{|c|c|c|c|c|c|c|c|c|c|c|c|c|}
\hline Step & $\begin{array}{c}\text { Monitored } \\
\text { Displacement }\end{array}$ & $\begin{array}{l}\text { Base } \\
\text { Force }\end{array}$ & A-B & B-C & C-D & D-E & $>\mathbf{E}$ & $\begin{array}{l}\text { A- } \\
\text { IO }\end{array}$ & $\begin{array}{l}\text { IO- } \\
\text { LS }\end{array}$ & $\begin{array}{l}\text { LS- } \\
\text { CP }\end{array}$ & $\stackrel{>}{\mathrm{CP}}$ & Total \\
\hline & $\mathrm{mm}$ & $\mathbf{k N}$ & & & & & & & & & & \\
\hline 0 & 0 & 0 & 2304 & 0 & 0 & 0 & 0 & 2304 & 0 & 0 & 0 & 2304 \\
\hline 1 & 49.203 & 2431.166 & 2300 & 4 & 0 & 0 & 0 & 2304 & 0 & 0 & 0 & 2304 \\
\hline 2 & 119.779 & 5107.6012 & 2134 & 170 & 0 & 0 & 0 & 2290 & 12 & 0 & 2 & 2304 \\
\hline 3 & 138.681 & 5427.9434 & 2044 & 260 & 0 & 0 & 0 & 2214 & 58 & 0 & 32 & 2304 \\
\hline 4 & 166.498 & 5699.4491 & 2008 & 296 & 0 & 0 & 0 & 2124 & 100 & 0 & 80 & 2304 \\
\hline 5 & 175.735 & 5757.0018 & 2008 & 296 & 0 & 0 & 0 & 2120 & 96 & 0 & 88 & 2304 \\
\hline 6 & 190.911 & 5907.4911 & 1964 & 340 & 0 & 0 & 0 & 2100 & 98 & 4 & 102 & 2304 \\
\hline 7 & 196.797 & 5940.5036 & 1964 & 340 & 0 & 0 & 0 & 2092 & 106 & 4 & 102 & 2304 \\
\hline 8 & 211.079 & 6055.2498 & 1924 & 380 & 0 & 0 & 0 & 2060 & 106 & 28 & 110 & 2304 \\
\hline 9 & 221.27 & 6090.9295 & 1924 & 380 & 0 & 0 & 0 & 2044 & 118 & 32 & 110 & 2304 \\
\hline 10 & 231.605 & 6192.6891 & 1908 & 396 & 0 & 0 & 0 & 2040 & 110 & 40 & 114 & 2304 \\
\hline 11 & 284.39 & 6532.1036 & 1888 & 416 & 0 & 0 & 0 & 2020 & 78 & 56 & 150 & 2304 \\
\hline 12 & 311.969 & 6630.8033 & 1888 & 416 & 0 & 0 & 0 & 2016 & 76 & 24 & 188 & 2304 \\
\hline 13 & 330.074 & 6774.1355 & 1884 & 408 & 12 & 0 & 0 & 2016 & 76 & 12 & 200 & 2304 \\
\hline 14 & 345.482 & 6854.5082 & 1876 & 412 & 16 & 0 & 0 & 2016 & 68 & 20 & 200 & 2304 \\
\hline 15 & 348.384 & 6860.8295 & 1876 & 412 & 16 & 0 & 0 & 2016 & 68 & 20 & 200 & 2304 \\
\hline 16 & 350.673 & 6870.6882 & 1872 & 408 & 24 & 0 & 0 & 2016 & 68 & 20 & 200 & 2304 \\
\hline 17 & 350.769 & 6870.4183 & 1872 & 408 & 24 & 0 & 0 & 2016 & 68 & 18 & 202 & 2304 \\
\hline 18 & 350.863 & 6871.0572 & 1872 & 408 & 24 & 0 & 0 & 2016 & 68 & 18 & 202 & 2304 \\
\hline 19 & 350.875 & 6870.4538 & 1872 & 408 & 24 & 0 & 0 & 2016 & 68 & 18 & 202 & 2304 \\
\hline 20 & 350.876 & 6870.469 & 1872 & 408 & 24 & 0 & 0 & 2016 & 68 & 18 & 202 & 2304 \\
\hline 21 & 350.883 & 6867.7953 & 1872 & 408 & 24 & 0 & 0 & 2016 & 68 & 18 & 202 & 2304 \\
\hline 22 & 350.979 & 6868.443 & 1872 & 407 & 25 & 0 & 0 & 2016 & 68 & 18 & 202 & 2304 \\
\hline 23 & 350.98 & 6868.4995 & 1872 & 407 & 25 & 0 & 0 & 2016 & 68 & 18 & 202 & 2304 \\
\hline
\end{tabular}

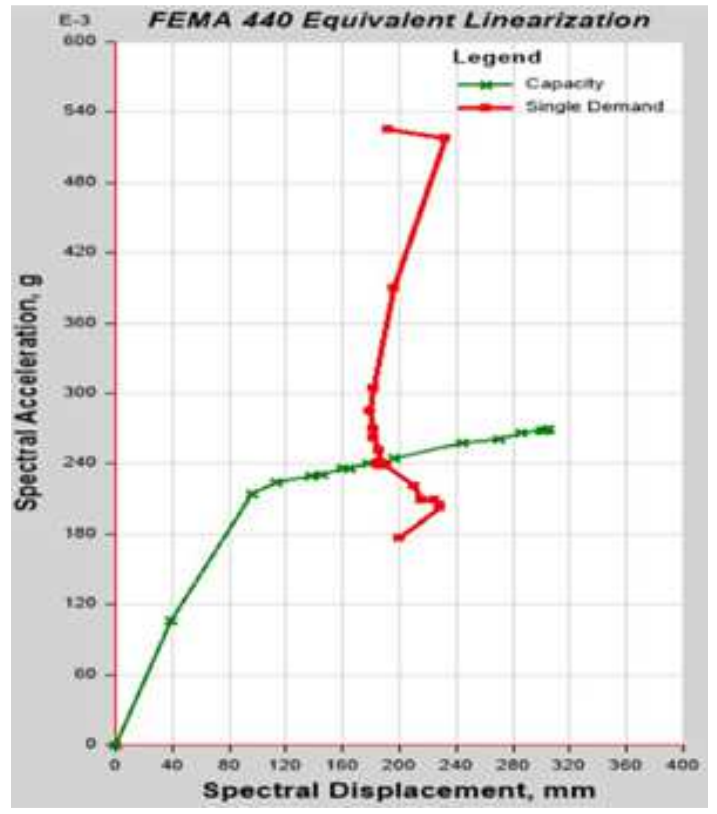

Figure 6: Spectral Acceleration vs Spectral Displacement for G+5 Story. 


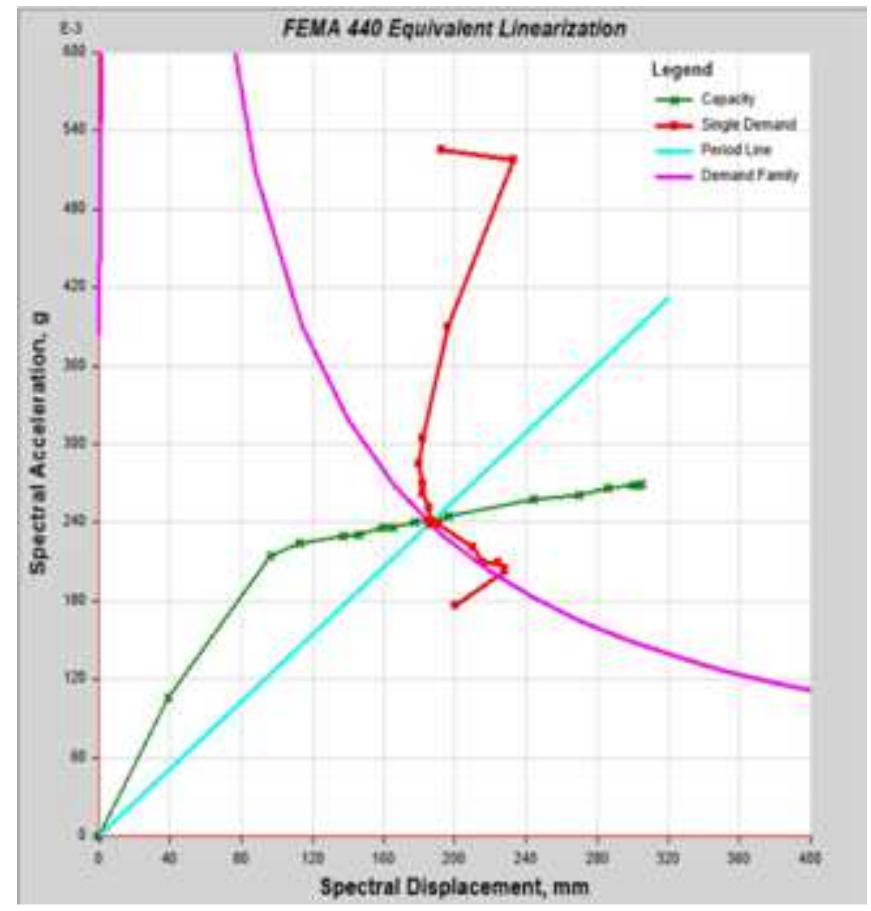

Figure 7: Detailed Results of FEMA 440 Graph Concerning the Demand Curve for G+5 Frame.

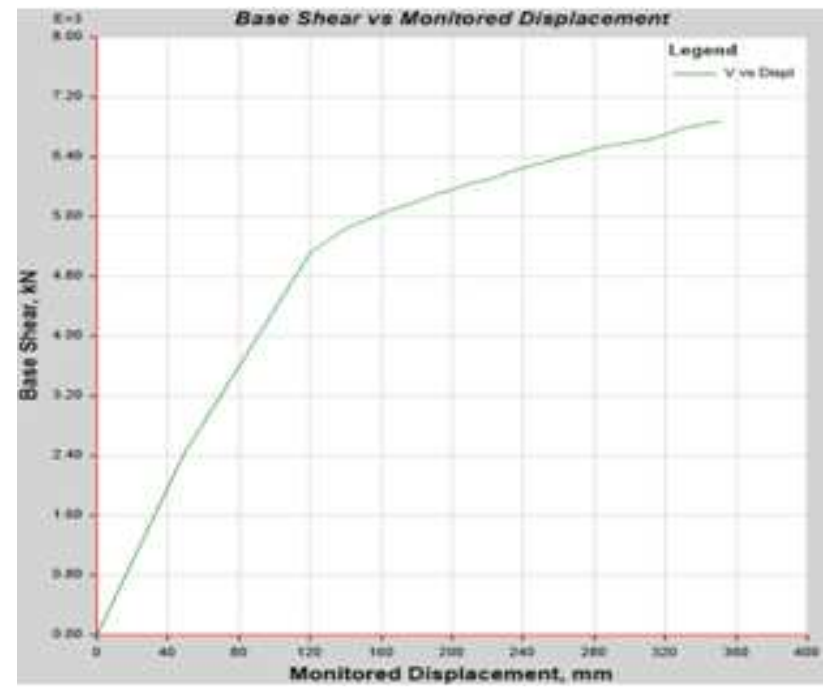

Figure 7: Variation of Base Shear vs Monitored Displacement for G+5 Frame.

\section{Interpretation of G+8 Frame}

Stressing on the performance of the 9 story building shown in Table 2 and Figure 11, the origin of hinges first observed at $95.15 \mathrm{~mm}$ displacement and maximum displacement noticed is $423.63 \mathrm{~mm}$ at $7790.28 \mathrm{kN}$ base force and after that, it is observed that base force starts dropping. Straining on the results of the FEMA 440 curve in Figure 10, $7407.5 \mathrm{kN}$ is observed as a performance point at $318.8 \mathrm{~mm}$ displacement with a ductility ratio of 1.77 , T-secant as $2.29 \mathrm{~s}$, T-effective as $2.05 \mathrm{~s}$. and spectral acceleration is observed as 0.2 corresponding to the spectral displacement of $261.51 \mathrm{~mm}$. 
Table 2: Base Shear vs Monitored Displacement for G+8 Building

\begin{tabular}{|c|c|c|c|c|c|c|c|c|c|c|c|c|}
\hline Step & $\begin{array}{c}\text { Monitored } \\
\text { Displ }\end{array}$ & Base Force & A-B & B-C & C-D & D-E & $>\mathbf{E}$ & A-IO & IO-LS & LS-CP & $>\mathrm{CP}$ & Total \\
\hline & $\mathbf{m m}$ & kN & & & & & & & & & & \\
\hline 0 & 0 & 0 & 3456 & 0 & 0 & 0 & 0 & 3456 & 0 & 0 & 0 & 3456 \\
\hline 1 & 95.154 & 3014.3798 & 3452 & 4 & 0 & 0 & 0 & 3456 & 0 & 0 & 0 & 3456 \\
\hline 2 & 213.638 & 6336.5685 & 3356 & 100 & 0 & 0 & 0 & 3436 & 12 & 0 & 8 & 3456 \\
\hline 3 & 233.42 & 6798.4041 & 3276 & 180 & 0 & 0 & 0 & 3404 & 24 & 0 & 28 & 3456 \\
\hline 4 & 233.43 & 6791.4421 & 3268 & 188 & 0 & 0 & 0 & 3404 & 24 & 0 & 28 & 3456 \\
\hline 5 & 233.441 & 6788.489 & 3268 & 188 & 0 & 0 & 0 & 3404 & 24 & 0 & 28 & 3456 \\
\hline 6 & 234.095 & 6801.8851 & 3268 & 188 & 0 & 0 & 0 & 3404 & 24 & 0 & 28 & 3456 \\
\hline 7 & 234.106 & 6799.3535 & 3268 & 188 & 0 & 0 & 0 & 3404 & 24 & 0 & 28 & 3456 \\
\hline 8 & 244.843 & 6972.7104 & 3220 & 236 & 0 & 0 & 0 & 3384 & 44 & 0 & 28 & 3456 \\
\hline 9 & 252.319 & 7054.6829 & 3184 & 272 & 0 & 0 & 0 & 3384 & 40 & 0 & 32 & 3456 \\
\hline 10 & 254.047 & 7063.6348 & 3172 & 284 & 0 & 0 & 0 & 3384 & 40 & 0 & 32 & 3456 \\
\hline 11 & 258.278 & 7104.3111 & 3160 & 296 & 0 & 0 & 0 & 3384 & 38 & 0 & 34 & 3456 \\
\hline 12 & 264.868 & 7140.9565 & 3144 & 312 & 0 & 0 & 0 & 3384 & 38 & 0 & 34 & 3456 \\
\hline 13 & 268.978 & 7175.7174 & 3136 & 320 & 0 & 0 & 0 & 3384 & 36 & 0 & 36 & 3456 \\
\hline 14 & 273.931 & 7196.2584 & 3132 & 324 & 0 & 0 & 0 & 3368 & 52 & 0 & 36 & 3456 \\
\hline 15 & 276.978 & 7221.1857 & 3128 & 328 & 0 & 0 & 0 & 3352 & 68 & 0 & 36 & 3456 \\
\hline 16 & 331.745 & 7465.0609 & 3040 & 416 & 0 & 0 & 0 & 3264 & 116 & 36 & 40 & 3456 \\
\hline 17 & 390.307 & 7664.2907 & 3008 & 448 & 0 & 0 & 0 & 3180 & 128 & 48 & 100 & 3456 \\
\hline 18 & 393.128 & 7681.2448 & 3000 & 456 & 0 & 0 & 0 & 3172 & 128 & 48 & 108 & 3456 \\
\hline 19 & 418.546 & 7767.1875 & 2992 & 452 & 12 & 0 & 0 & 3148 & 124 & 40 & 144 & 3456 \\
\hline 20 & 419.649 & 7767.4533 & 2990 & 454 & 12 & 0 & 0 & 3148 & 124 & 40 & 144 & 3456 \\
\hline 21 & 419.697 & 7767.4553 & 2990 & 454 & 12 & 0 & 0 & 3148 & 124 & 40 & 144 & 3456 \\
\hline 22 & 419.697 & 7767.456 & 2990 & 454 & 12 & 0 & 0 & 3148 & 124 & 40 & 144 & 3456 \\
\hline 23 & 419.708 & 7761.6196 & 2990 & 454 & 12 & 0 & 0 & 3148 & 124 & 40 & 144 & 3456 \\
\hline 24 & 422.751 & 7790.2699 & 2986 & 458 & 12 & 0 & 0 & 3148 & 124 & 40 & 144 & 3456 \\
\hline 25 & 423.633 & 7790.2858 & 2986 & 458 & 12 & 0 & 0 & 3148 & 122 & 40 & 146 & 3456 \\
\hline 26 & 423.643 & 7732.8721 & 2986 & 448 & 22 & 0 & 0 & 3146 & 124 & 40 & 146 & 3456 \\
\hline 27 & 423.491 & 7722.5155 & 2986 & 447 & 23 & 0 & 0 & 3146 & 124 & 40 & 146 & 3456 \\
\hline
\end{tabular}

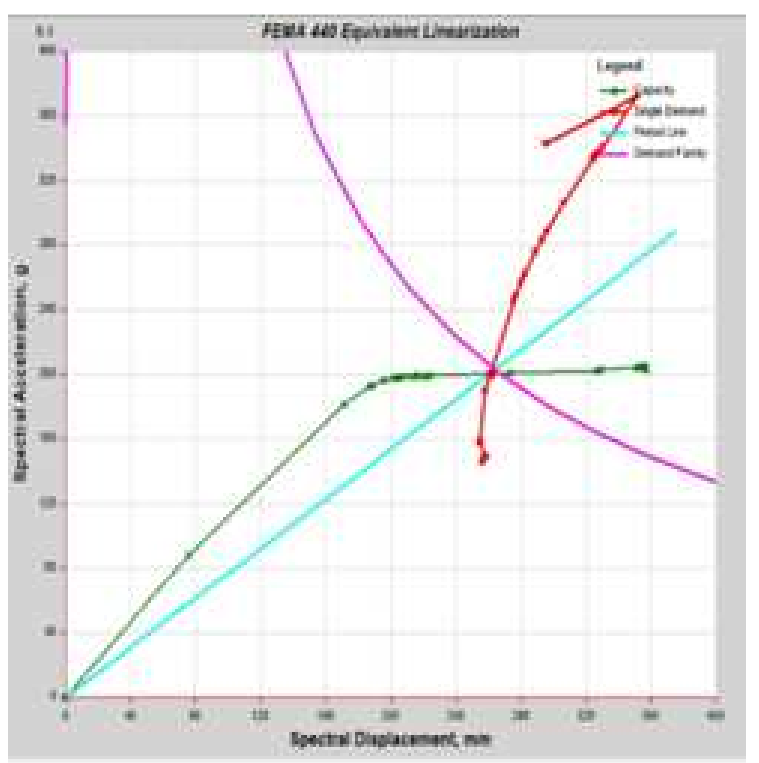

Figure 8: Detailed Results of FEMA 440 Graph Concerning the Demand Curve for $\mathbf{G}+8$ Frame. 


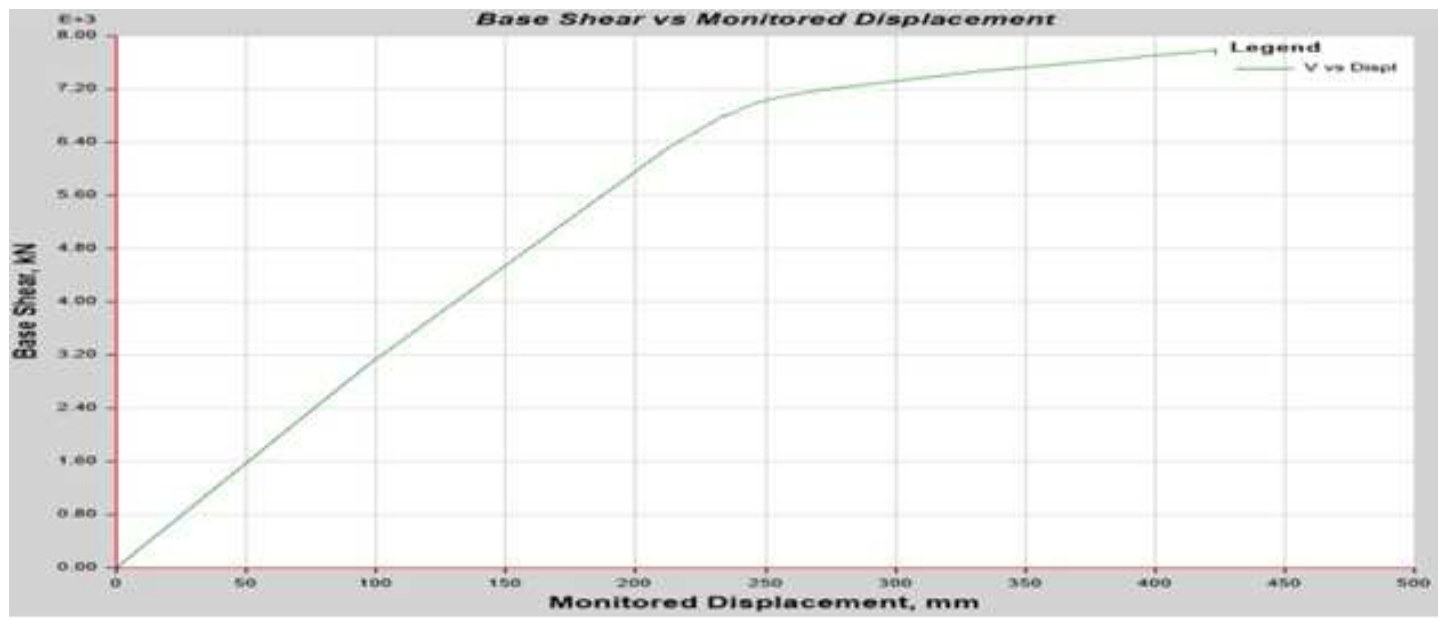

Figure 9: Variation of Base Shear vs Monitored Displacement for G+8 Frame.

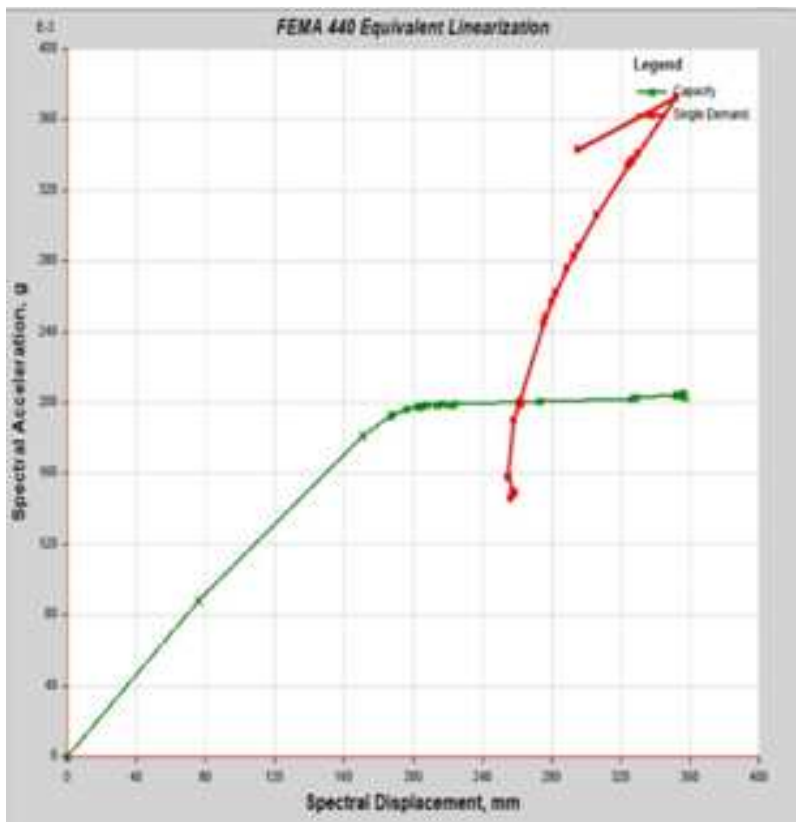

Figure 10: Spectral Acceleration vs Spectral Displacement for G+8 Story.

\section{Interpretation of $\mathbf{G + 1 2}$ Frame}

Incorporating the performance of 13 story buildings shown in Table 3 and Figure 14, the origin of hinges first observed at $195 \mathrm{~mm}$ displacement and maximum displacement noticed is $750.04 \mathrm{~mm}$ at $9140.72 \mathrm{kN}$ base force and after that, it is observed that base force starts dropping. Straining on the results of FEMA 440 curve in Figure $137972.61 \mathrm{kN}$ is observed as performance point at $502.8 \mathrm{~mm}$ displacement with ductility ratio of 1.90 , T-secant as $3.31 \mathrm{~s}$, T-effective as $3.13 \mathrm{~s}$ and spectral acceleration is observed as 0.15 corresponding to the spectral displacement of $411.35 \mathrm{~mm}$ 
Table 3: Base Shear vs Monitored Displacement for G+12 Building

\begin{tabular}{|c|c|c|c|c|c|c|c|c|c|c|c|c|}
\hline Step & $\begin{array}{l}\text { Monitored } \\
\text { Displacement }\end{array}$ & Base Force & A-B & B-C & C-D & D- & $\begin{array}{l}> \\
\mathbf{E}\end{array}$ & A-IO & $\begin{array}{l}\text { IO- } \\
\text { LS }\end{array}$ & $\begin{array}{l}\text { LS- } \\
\text { CP }\end{array}$ & $\begin{array}{l}>C \\
P\end{array}$ & Total \\
\hline & $\mathbf{m m}$ & kN & & & & & & & & & & \\
\hline 0 & 0 & 0 & 4992 & 0 & 0 & 0 & 0 & 4992 & 0 & 0 & 0 & 4992 \\
\hline 1 & 156 & 3254.6294 & 4992 & 0 & 0 & 0 & 0 & 4992 & 0 & 0 & 0 & 4992 \\
\hline 2 & 195.725 & 4083.4057 & 4976 & 16 & 0 & 0 & 0 & 4992 & 0 & 0 & 0 & 4992 \\
\hline 3 & 357.727 & 6769.3559 & 4768 & 224 & 0 & 0 & 0 & 4920 & 56 & 0 & 16 & 4992 \\
\hline 4 & 410.854 & 7354.6083 & 4624 & 368 & 0 & 0 & 0 & 4884 & 48 & 0 & 60 & 4992 \\
\hline 5 & 523.768 & 13.8764 & 4476 & 516 & 0 & 0 & 0 & 4668 & 92 & 0 & 232 & 4992 \\
\hline 6 & 688.624 & 8935.0623 & 4356 & 632 & 4 & 0 & 0 & 4560 & 104 & 12 & 316 & 4992 \\
\hline 7 & 722.99 & 9089.6019 & 4328 & 648 & 16 & 0 & 0 & 4544 & 102 & 26 & 320 & 4992 \\
\hline 8 & 741.406 & 9141.3774 & 4322 & 650 & 20 & 0 & 0 & 4544 & 96 & 28 & 324 & 4992 \\
\hline 9 & 744.176 & 9144.1278 & 4322 & 650 & 20 & 0 & 0 & 4544 & 96 & 28 & 324 & 4992 \\
\hline 10 & 746.925 & 9138.2765 & 4322 & 650 & 20 & 0 & 0 & 4544 & 96 & 28 & 324 & 4992 \\
\hline 11 & & & 4322 & 650 & 20 & 0 & 0 & 4544 & 96 & 28 & 324 & 4992 \\
\hline 12 & 747.963 & 9097.3919 & 4322 & 650 & 20 & 0 & 0 & 4544 & 96 & 28 & 324 & 4992 \\
\hline
\end{tabular}

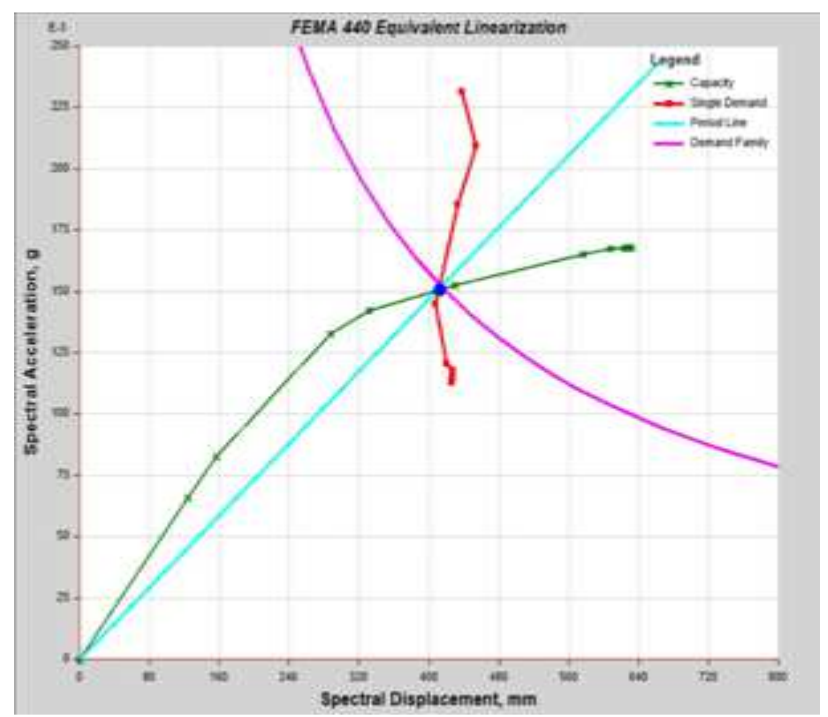

Figure 11: Detailed Results of FEMA 440 Graph Concerning the Demand Curve for G+12 Frame.

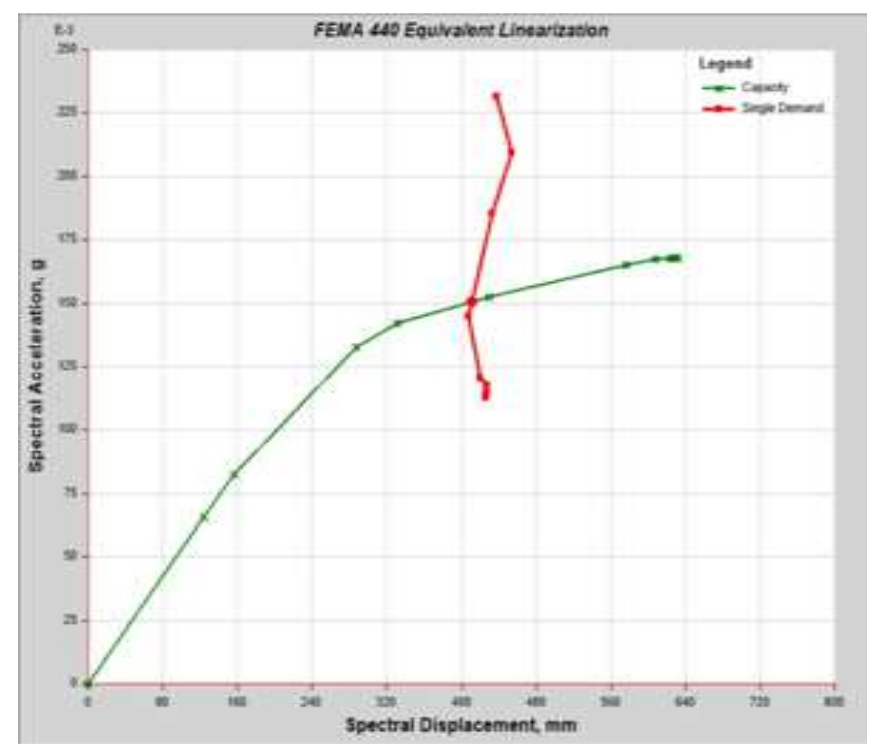

Figure 12: Spectral Acceleration vs Spectral Displacement for G+12 Story. 


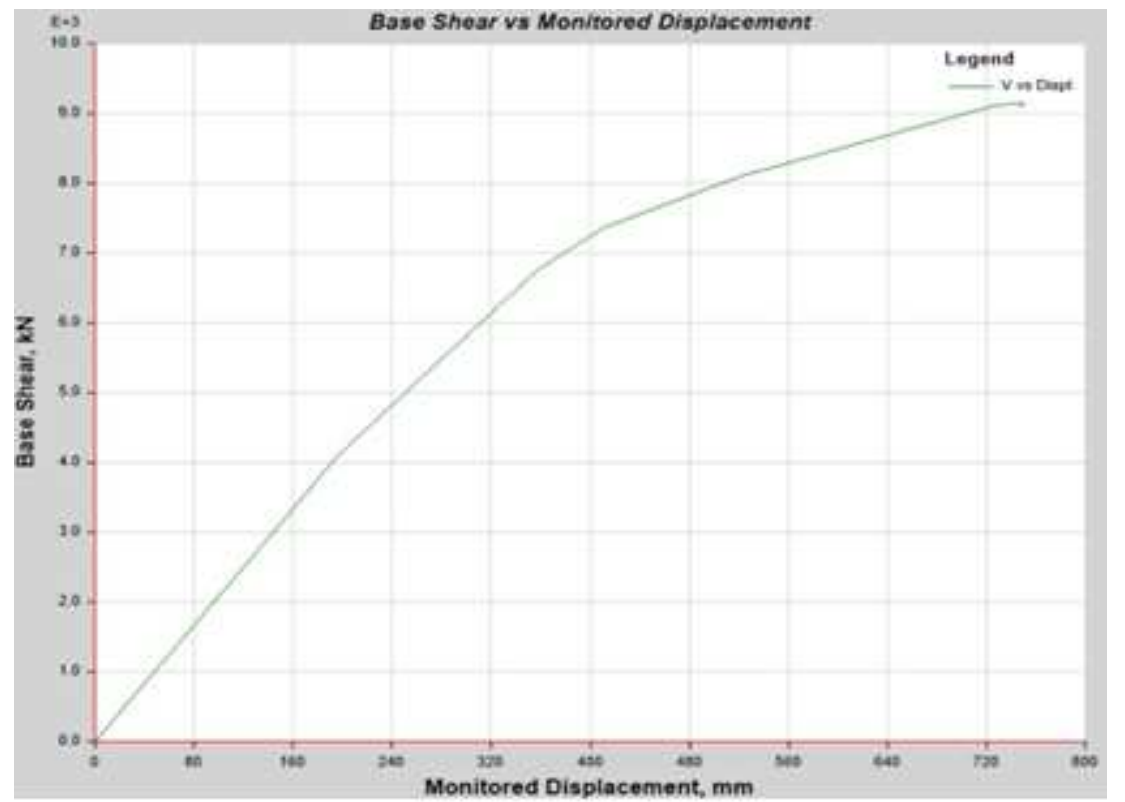

Figure 13: Variation of Base Shear vs Monitored Displacement for G+12 Frame.

\section{CONCLUSIONS}

Concluding the analytical results of non-linear static pushover analysis, the dimensions of beam and column highly influenced the design capacity of the structure and the concept of weak beam strong column is highly recommended for performance-based design. Straining on the code recommendation and the analytical results, there is a clear indication of the strong influence of moment capacity on the ductility of the column and further the frame follows the assorted array in which extremity node at ground level illustrates the formation of hinges and rest follows beam mechanism. Concluding the maximum displacement and corresponding base shear, the results show that the maximum displacement and base shear are directly related to several storey's, as in G+5 the maximum displacement is $350 \mathrm{~mm}$ corresponding to $6870 \mathrm{kN}$ base force, similarly for $\mathrm{G}+8$, displacement up to dropping of base shear $423 \mathrm{~mm}$ corresponding to $7790 \mathrm{kN}$ base force and for $\mathrm{G}+12$ frame it is $750 \mathrm{~mm}$ and $9140 \mathrm{kN}$ base force which indicate an increase of maximum displacement and base shear as an increase in several stories.

Another aspect of the study depicts that the performance point observed for $\mathrm{G}+5, \mathrm{G}+8$, and $\mathrm{G}+12$ frame as $6870.68 \mathrm{kN}, 7790.28 \mathrm{kN}$, and $9140.72 \mathrm{kN}$ which surprisal shows a rapid increase in performance point but later increment is low. Contrasting on the displacement at performance point for $\mathrm{G}+5, \mathrm{G}+8$, and $\mathrm{G}+12$ is $220.8,318.8$ and 502.8, which shows $44.38 \%$ increment in displacement from $\mathrm{G}+5$ to $\mathrm{G}+8$, and $57.71 \%$ increment in displacement from $\mathrm{G}+8$ to $\mathrm{G}+12$

\section{REFERENCES}

1. Kissi.B, Riyad. Y, Mrani.I, Parron, M.A, Labjar,N, Haouzi.A, ElEl Fqih. M, Ait Guemimi, C 2018, Influence of zone type on the performance of retrofitted Reinforced Concrete buildings by Using Pushover Analysis, journal of Materials Today: Proceedings, Vol. 5, Issue 1, pp 22-29.

2. Al-Jassim, Samir A B Jabbar, \&Husssain, Mohanned Abdul, Pushover Analysis of $G+5$ Reinforced Concrete Building in Basrah, International Journal of Innovations in Engineering and Technology (IJIET), ISSN: 2319-1058, Vol. 11, Issue, August 2018, pp. 53-59. 
3. Naik Pramodini, \&Annigeri Satish, 2017, Performance evaluation of 9 storey RC building located in North Goa, 11th International Symposium on Plasticity and Impact Mechanics, Implant 2016, Procedia Engineering 173 (2017), pp. 18411846.

4. Priyanka, Bhave, \& Mayur, Banaras, Analysis, and Capacity Based Earthquake Resistance Design of Multy Bay Multy Storeyed Residential Building, Int. Journal of Engineering Research and Applications www.ijera.com ISSN: 2248-9622, Vol. 6, Issue 4, (Part - 5) April 2016, pp.78-84

5. Ravi, Avula, \& Reddy, Teja, 2015, Design of RC framed building considering MCRs recommended in various international codes, (online), Assessed 20-10-18 http://ethesis.nitrkl.ac.in/7476/1/2015_BT_design_Reddy.pd

6. Cagurangan, Colleen Kirsten, 2015, Effects of Strong-Column Weak-Beam Ratios on Collapse Capacities of Tall Reinforced Concrete Moment Frame Structures, Ph D. Thesis, University of California, Berkeley.

7. Swamy, B Shivakumara\&Prasad, S K, Influence of strong column and weak beam concept, soil type and zone on performance of RC frames, Volume: 04 Special Issue: 04 | ASHCE-2015|May-2015,pp.61-76, Available @ http://www.ijret.org

8. Hadigheh, S A, Maheri, Mahmoud R, Mahini, S S, 2013, Performance of strong column and weak beam RC frames strengthened at the joint by FRP, IJST, Transactions of Civil Engineering, Vol. 37, No. C1, pp 33-51, Printed in The Islamic Republic of Iran, 2013@ Shiraz University

9. Leslie, Rahul, Design, Buildings, The Pushover Analysis, explained in its Simplicity, proceedings of 2nd national conferenceRACE13 at Saintgits College of engineering, Kottayam.

10. Liu, Yangbing, Liao, Yuanxin, Zheng, Nina, 2012, Analysis of Strong Column and Weak Beam Behavior of Steel-concrete Mixed Frames, 15 world conference on earthquake engineering, lisboa 2012, pp.2-7

11. Bento, Rita, 2000, Evolution of the need of strong column and weak beam design in dual frame wall structures, 12 world conference on earthquake engineering, Auckland,2000, ppl-7.

12. Yang, Pu, Wang, Yayong, 1940, A study on improvement of pushover analysis, 12 world conference on earthquake engineering, Auckland, 2000, pp.19-40.

13. Magenes, Guido,1866, A method for pushover analysis in seismic assessment of masonry buildings, 12 world conference on earthquake engineering, Auckland,2000, paper no 1866

14. “BIS IS 456: Plain and reinforced concrete-code of practice. New Delhi (India): Bureau of Indian Standards; 2000”.

15. “BIS IS 1893: Criteria for earthquake resistant design of structures, Part 1. New Delhi (India): Bureau of Indian Standards; 2002".

16. “BIS IS 13920: Ductile detailing of reinforced concrete structures subjected to seismic forces-code of practice. New Delhi (India): Bureau of Indian Standards; 1993”.

17. “BIS IS 875: Code Of Practice For Design Loads For Buildings And Structures, Part 2. New Delhi (India): Bureau of Indian Standards; 1987".

18. Paulay, T., Park, R., and Priestley, M. J. N., “Reinforced Concrete Beam-Column JointsUnder Seismic Actions.” ACI Journal, 1978, pp 585-59.

19. FEMA 356, (2000), Pre standard and commentary for the seismic rehabilitation of buildings, American society of civil engineers, Reston VA. 
20. Suriansyah, I., M. Afifuddin, and M. Hasan. "Performance of Asymmetric Building Structure with Base Isolator Using Pushover Analysis." International Journal of Civil, Structural, Environmental and Infrastructure Engineering Research and Development (IJCSEIERD) 10.2 (2020):1-8

21. Nezami, Mohsen, and Mozhgan Rahi. "Fragility Analysis of Existing Steel Building and Possible Rehabilitation by Fuzzy Expert Systems Under Blast and Dynamic Loads." International Journal of Civil, Structural, Environmental and Infrastructure Engineering Research and Development (IJCSEIERD) 6.3 (2016): 1-12.

22. Paul, Theresa, and Nivin Philip. "Influence of Pretwisting Angle on the Buckling Capacity of Steel Columns: A Review." International Journal of Civil Engineering (IJCE) 5.6 (2016): 1-10.

23. Bandyopadhyay, Milan, Mohamed Ahmed Galal, and Atul Krishna Banik. "Performance Of Retrofitted Semi-Rigid Jointed Steel Frames In Progressive Collapse Events." International Journal of Mechanical and Production Engineering Research and Development (IJMPERD) Special Issue (2018):209-216 